\title{
Serving low-income markets: rethinking multinational corporations' strategies
}

Citation for published version (APA):

SadreGhazi, S., \& Duysters, G. M. (2008). Serving low-income markets: rethinking multinational corporations' strategies. UNU-MERIT, Maastricht Economic and Social Research and Training Centre on Innovation and Technology. UNU-MERIT Working Papers No. 024

Document status and date:

Published: 01/01/2008

Document Version:

Publisher's PDF, also known as Version of record

\section{Please check the document version of this publication:}

- A submitted manuscript is the version of the article upon submission and before peer-review. There can be important differences between the submitted version and the official published version of record.

People interested in the research are advised to contact the author for the final version of the publication, or visit the DOI to the publisher's website.

- The final author version and the galley proof are versions of the publication after peer review.

- The final published version features the final layout of the paper including the volume, issue and page numbers.

Link to publication

\footnotetext{
General rights rights.

- You may freely distribute the URL identifying the publication in the public portal. please follow below link for the End User Agreement:

www.umlib.nl/taverne-license

Take down policy

If you believe that this document breaches copyright please contact us at:

repository@maastrichtuniversity.nl

providing details and we will investigate your claim.
}

Copyright and moral rights for the publications made accessible in the public portal are retained by the authors and/or other copyright owners and it is a condition of accessing publications that users recognise and abide by the legal requirements associated with these

- Users may download and print one copy of any publication from the public portal for the purpose of private study or research.

- You may not further distribute the material or use it for any profit-making activity or commercial gain

If the publication is distributed under the terms of Article $25 \mathrm{fa}$ of the Dutch Copyright Act, indicated by the "Taverne" license above, 


\section{UNITED NATIONS \\ UNIVERSITY}

\section{UNU-MERIT}

\section{Working Paper Series}

\#2008-024

Serving low-income markets:

Rethinking Multinational Corporations' Strategies

Shuan SadreGhazi and Geert Duysters

(United Nations University-MERIT) 


\title{
Serving low-income markets: Rethinking Multinational Corporations' Strategies ${ }^{*}$
}

\author{
Shuan SadreGhazi and Geert Duysters \\ (United Nations University-MERIT)
}

\begin{abstract}
In recent years a new debate is emerging about market-based approaches to serve lowincome communities, opportunities in such markets and the role of multinational corporations. This paper aims at providing an overview of low-income markets thereby analyzing challenges that multinational corporations face in addressing such markets. Various examples of low-income market approaches are examined and different firm strategies regarding R\&D, production and distribution in such markets have been illustrated and discussed. It is argued why specific strategies, many of them new to multinationals, are to be devised when it comes to serving low-income communities.
\end{abstract}

Key words: Multinational corporations, Low-income markets, Bottom of the Pyramid, Business strategy

JEL codes: F23, M19, O32, O19

\section{UNU-MERIT Working Papers \\ ISSN 1871-9872}

\author{
Maastricht Economic and social Research and training centre on Innovation and \\ Technology, UNU-MERIT
}

\section{UNU-MERIT Working Papers intend to disseminate preliminary results of research carried out at the Centre to stimulate discussion on the issues raised.}

\footnotetext{
* This paper is under editorial revision and will be published in the forthcoming book: Costa, I.; Duysters, G. and Dolfsma, W. (eds): "Multinational and emerging economies: the quest for development and sustainability" (Edwar Elgar). The authors would like to thank Annabel Marin, Rajeesh Kumar and other authors in the book for their comments on the earlier versions of this chapter.
} 


\section{Introduction}

There is an ongoing debate in the academic literature about the role and impact of multinational corporations in developing countries. Some of the views are very skeptical and consider multinationals activities in developing countries as a new way of exploitation (Porritt 2005:253), while others view multinational corporations as giant engines of economic growth that can become the new wellsprings of prosperity to developing economies (e.g Prahalad, 2005; Hart, 2005). Alongside these discussions we see an ongoing trend in which many multinational companies try to build a positive image by engaging in philanthropic and corporate social responsibility projects.

Recently, a new debate is emerging about market-based approaches to addressing low-income markets in developing countries and about the main motivations that drive these approaches. These approaches are diverse and can range from poverty alleviation to pure profit driven attempts. This chapter aims to provide an overview of low-income markets thereby analyzing challenges and opportunities that multinational corporations face in addressing such markets.

Higher-income markets, despite their smaller population in a global comparison to lowincome markets have, for a long time, been the most attractive marketplace for large corporations. Consequently a large part of the world population with lower income levels, has been ignored as an attractive market by both multinational corporations and large domestic companies. It is not the size of the market that made them relatively unattractive. The general lack of purchasing power from these markets and infrastructure issues were commonly considered as major problems that made it very unattractive for companies to invest heavily into these markets. Fact is, however, that more than two thirds of the world population resides in the lower-income tier of the 
world economic pyramid (also known as the Base/Bottom of the Pyramid - BOP). Despite the fact that the size of these markets is much larger than the markets at the top of the economic pyramid, there are still only very few products and services developed particularly to satisfy the needs of the users in the base of the pyramid.

It is widely argued that a large share of the world population, those who live in the lowincome communities of developing copuntries, are not adequately included in the global economy and have limited access to products, markets and opportunities to develop themselves (Prahalad, 2005; Hammond et al, 2007). Similarly, their lack of resources discourages companies from providing the basic goods and services that would empower them and would improve their lives. Those who encourage market-based approaches argue that finding appropriate ways to satisfy the unmet needs of lowerincome communities can bring enhanced opportunities for these communities, in terms of access to better products as well as in terms of employment. On the other hand, businesses firms can benefit from the opportunities that have the potential to foster their long-term growth (UNDP, 2007; Rangan et al, 2007; Hammond et al. 2007; Prahalad, 2005; Hart, 2005; Grayson and Hodges,2004).

Although the importance of international aid for serving unmet needs is not ruled out, aid and philanthropy approaches face some limitations in terms of scale and sustainability. Furthermore, donors and non-profit organizations are also seeking more effective approaches to their aid efforts and some look for alternative ways to help out underserved communities, for instance by joining forces with the private sector (see for example Brugmann and Prahalad, 2007). 
Because of the limited economic opportunities, so far low-income communities have often been unable to contribute to or benefit from growing market economies. Furthermore, even when such opportunities do occur, the poor are generally unable to take advantage of these opportunities because they often lack good health, education and credit. If market-based approaches are going to contribute to their development and make a difference, there is a need for a deeper understanding about the characteristics of these communities and their dynamics.

\section{What is in the Base of the Pyramid?}

Recently the idea of market approach to address low-income communities (also known as Bottom / Base of the Pyramid) has gathered increased momentum, both in theory and practice. Early works (e.g. Hart and Milstein, 1999, Hart and Christensen, 2002; Prahalad and Hart, 2002, Hammond and Prahalad, 2004) have focused on articulating the strategic logic for pursuing business strategies aimed at low-income communities. The phrase and concept of the "Bottom of the Pyramid" originates from the seminal work of Stuart Hart and C.K. Prahalad (2002:1) "The Fortune at the Bottom of the Pyramid" :

"This is a time for multinational corporations to look at globalization strategies through a new lens of inclusive capitalism. For companies with the resources and persistence to compete at the bottom of the world economic pyramid, the prospective rewards include growth, profits, and incalculable contributions to humankind. Countries that still don't have the modern infrastructure or products to meet basic human needs are an ideal testing ground for developing 
environmentally sustainable technologies and products for the entire world. "

In the base of the pyramid approach, the global population is divided into segments based on purchasing power parity $(\mathrm{PPP})^{\mathrm{i}}$.. There is still no consensus about the proper way to define base of the pyramid population. Different authors on low-income markets have articulated different PPP lines, depending on the way they define low-income and bottom of the income pyramid, Different PPP lines have been articulated in the academic literature ranging from $\$ 1500$ - $\$ 3000$ per annum to $\$ 1$ - $\$ 2$ per day (WRI, 2007; Prahalad, 2005; Prahalad and Hart, 2002). This inconsistency in measuring the base of the income pyramid has received some criticism (Karnani, 2007). More recently, the World Resource Institute (2007) conducted a study to analyze the size and aggregate purchasing of the BoP (see for example Table 1).

\begin{tabular}{|c|c|c|c|c|}
\hline & $\begin{array}{l}\text { BOP } \\
\text { population } \\
\text { (millions) }\end{array}$ & $\begin{array}{l}\text { BOP share of } \\
\text { total population } \\
(\%)\end{array}$ & $\begin{array}{l}\text { BOP income } \\
\text { (PPP, US\$) }\end{array}$ & $\begin{array}{l}\text { BOP } \\
\text { share of } \\
\text { total } \\
\text { income } \\
(\%)\end{array}$ \\
\hline Africa & 486 & 95.1 & 429,000 & 70.5 \\
\hline Asia & 2858 & 83.4 & $3,470,000$ & 41.7 \\
\hline Eastern Europe & 254 & 63.8 & 458,000 & 36 \\
\hline $\begin{array}{l}\text { Latin America and } \\
\text { Carribbean }\end{array}$ & 360 & 69.9 & 509,000 & 28,2 \\
\hline Total & 3,958 & 312.2 & $4,866,000$ & 148.2 \\
\hline
\end{tabular}

Table 1. BOP population and income, source: World Resources Institute (2007)

Although there have been some attempts by multinationals to serve those in extreme and moderate poverty (e.g P\&G's low-cost water purification devices and Philips' energy efficient wood stoves) the majority of initiatives fit the conditions of lower middle-income and upper low-income customers. In line with such an approach, that does not yet include those with extreme poverty, some use the label "the next billion" rather than talking about he whole base of the pyramid. There seems to be growing consensus that the potential of serving the whole BOP community has not been fulfilled and that most attention of global corporations is on serving lower middle and upper low- 
income customers.

\subsection{Market based approach to serving low-income communities}

Markets are not the only solution to the problems of low-income communities, but market-based approaches have some benefits that, if properly addressed, have the potential to contribute to both human development and business growth (UNDP, 2007). Proponents of market inclusion argue that consumers in lower-income communities can enjoy a better life if the business community offers them the ability to fulfill their basic needs for nutrition, health, education, housing and sanitation.

A market-based approach starts from the idea that having a low income does not eliminate market processes: almost all poor households trade cash or labor to meet their basic needs. A market-based approach to low-income markets considers local people as both consumers and agents that can be part of the business process (e.g as producers, distributors, promoters, etc). Such an approach can lead to creative solutions that can make markets more efficient and competitive and thus more beneficial for the communities who live in low-income communities (UNDP, 2007).

It is not always evident that large corporations have real advantages over small, local organizations. Multinational corporations may never be able to beat the cost or responsiveness of local entrepreneurs. In fact, empowering local entrepreneurs and enterprises seems to be key to developing solutions for poor communities. Still, there are some reasons why MNCs can play a role in serving low-income markets. Prahalad and Hart(2002) point to three capabilities of multinationals that give them the potential to play a positive role in addressing low-income markets :

- Resources. Building a complex commercial infrastructure for the base of the pyramid is a resource intensive activity. Developing BOP products and services requires significant research. Furthermore, distribution channels and communication networks are costly to develop and maintain. Not many local entrepreneurs have the managerial or technological resources to create such an infrastructure.

- Leverage. Multinationals can serve as agents that transfer knowledge from one market 
to another and scale-up the solutions. Although practices and products have to be customized to serve local needs, Multinationals, with their global knowledge base, have an advantage that is not easily accessible to local entrepreneurs. - Bridging. Multinationals can facilitate building the commercial infrastructure and providing access to knowledge and financial resources. They can act as catalysts to cooperate with NGOs, communities, local governments, entrepreneurs, and multilateral organizations in their attempts to bring development to underserved communities.

Because of the size and specific nature of the base of the pyramid, the scale and sustainability of the solutions seem to be of paramount importance in such a marketbased approach. A single sector approach, focusing on either government, aid agencies, non-profits or the private sector, is not likely to achieve the goal of serving the large scale of underserved communities alone. A partnership among various sectors seems therefore necessary to unlock and share the full potential. The private sector can

potentially act as an integrator of the various sectors and can make a positive contribution in development by taking an orchestration role in development initiatives. The strength of the private sector can potentially aid local entrepreneurs, firms, and communities in getting involved in innovation and investment, and help them to create jobs. The flows of income and the creative energy that they are able to generate may facilitate productive capacity and may provide a basis for mutual long-term development.

\subsection{Opportunities in low-income markets}

The opportunities associated with low-income markets are becoming gradually more apparent to firms (London and Hart, 2004). The majority of the population in these markets is primarily in the large but informal economies that are not counted in official statistics. It has been estimated that the informal sector around the world includes more than $\$ 9$ trillion in unregistered assets, This amount is close to the total value of all companies listed on the main stock exchanges of the 20 most developed (de Soto, 2000: 35). In addition to assets, the value of economic transactions in the informal markets might be even higher than what is recorded in the formal economic sectors in 
developing countries (Henderson, 1999). It is also argued that by getting engaged in BOP markets, multinationals can learn about important capabilities, practices and innovations that they might transfer to their higher-income markets (Christensen and Hart, 2002; Christensen et al, 2006) .

The report by the World Resources Institute (2007) indicates that the Asian BOP market has the largest size, with 2.86 billion population and a total income of $\$ 3.47$ trillion. It constitutes $83 \%$ of the region's total population and $42 \%$ of its aggregate purchasing power. Eastern Europe's $\$ 458$ billion BOP market includes 254 million people, $64 \%$ of the region's population, with $36 \%$ of aggregate purchasing power. In Latin America the BOP market of $\$ 509$ billion includes 360 million people, representing $70 \%$ of the region's population but only $28 \%$ of aggregate purchasing power, a smaller share than in other developing regions. In Africa, the BOP market is $\$ 429$ billion, but it represents $71 \%$ of aggregate purchasing power in this region. The African BOP includes 486 million people-95\% of the region's surveyed population.

The report also characterizes the base of the pyramid markets by sector. Analyzing the BOP market by sector shows that they range from those that are relatively small, such as water ( $\$ 20$ billion) and information and communication technologies ( $\$ 51$ billion), to medium-scale markets such as health ( $\$ 158$ billion), transportation ( $\$ 179$ billion), housing (\$332 billion), and energy ( $\$ 433$ billion), to very large markets, such as the food market ( $\$ 2,895$ billion).

These low-income markets have different levels of sophistication and risk. Some regions might face more challenges than others and those in the very bottom of the pyramid with extreme poverty might not directly benefit from the solutions offered to other low-income communities. Still, the aggregate market potential is higher than what can be expected from advanced markets of multinational corporations. 


\section{Multinationals' activities in developing countries}

Private sector firms are continually searching for new business opportunities. The growth of developed world markets is showing signs of slow down while shareholders and investors typically demanding double digit returns. Few organizations are likely to enjoy such level of growth in the long run. Furthermore, with the arrival of new competitors and new technologies, these already saturated markets are becoming more and more competitive (Hart and Christensen, 2002). Consequently, many firms try to broaden their opportunities by seeking new markets to increase revenues and to find new sources of supply to reduce costs. This has led to a greater attention to the markets in developing countries that are further down the economic pyramid (Dawar and Chattopadhyay, 2002; Prahalad and Lieberthal, 1998). Although these initiatives are aimed to serve the lower-income communities, they are different from corporate social responsibility and philanthropic activities of multinational in the developing world and are expected to translate into economic returns for the company.

From a historical perspective, operations of multinational corporations have, at times, faced hostility and resentment in developing countries. This is partly rooted in colonial domination times and clashes with the host countries' national interests (Caves, 2007:253). However, this hostility which was dominant during 70s has largely faded and an increasing number of countries in the developing world are actively encouraging foreign direct investment. Foreign direct investment through multinational corporations, has emerged in the last decade as the main source of foreign capital for developing countries (Ramamurti, 2004). 
Typically the operations of multinationals in developing countries fall into three main categories: export of natural resources, export of manufactured goods and serving the domestic market of the country (Caves, 2007:254). Although the first two categories have a longer history, the idea of serving local markets of developing countries has got onto steam during the 90s. Many multinationals rushed in to the large developing countries, often referred to as emerging markets, over the past decade, eagerly trying to fill the demands of the (potential) billions of new consumers. But in fact, the companies only addressed a tiny share of high income consumers in emerging markets who have global preferences and purchasing power similar to advanced markets. It was shown that it did not suffice to take on a global approach to developing markets. Recently, some companies are beginning to realize that they must delve deeper into the local consumer base in order to deliver on the promise of tapping into billion-consumer markets. But this calls for a shift in emphasis from fitting the available products and practices to a new approach that acknowledges the realities of the low-income communities. Products and programs transplanted from advanced markets to emerging markets only appeal to the affluent elite, which in emerging markets are no more than five per cent of the population (Dawar and Chattopadhyay, 2002).

It is argued that one of the reasons why so-called pro-poor innovations, formerly known as appropriate technologies, did not manage to diffuse in underserved communities is associated with the so-called scalability issue. Non-profit organizations that usually promote such innovations do not have the required resources to scale-up their solutions. In view of the lack of a mass-market the prospects of economies of scale would not yield enough profit to attract business actors. It was increasingly realized that delving 
deeper into the consumer base to establish mass-market positions would be the way to create the economies of scale necessary to justify production for low-income markets. This requires a specific understanding of the distinct conditions of low-income markets which are significantly different from mainstream markets of multinational corporations.

\section{Understanding low-income market characteristics}

The first step in addressing low-income markets in the developing world is understanding existing markets and their associated challenges and opportunities. In this section we explain the most important characteristics of low-income markets and provide examples where companies have tried to overcome the limitations of such markets.

\subsection{Low disposable income}

The most eminent characteristic of the communities at the base of the pyramid is their lower level of disposable income. This issue has other consequences which further complicate the use of mainstream business models of Multinationals in such a context. The problem of low disposable income manifests itself in two main ways (1) low purchasing power and (2) lack of access to credit.

The majority of the low-income communities have fluctuating daily rather than constant monthly income, which makes it difficult for them to have high one-off payments to buy goods and services. In higher-income regions consumers have the choice of getting access to credit and to buy expensive items. Banks however, usually don't provide such 
credits to those who don't have a constant monthly income. As a result in many lowincome countries people have to pay very high interests to the informal money lenders to overcome the credibility problem.

Often low-income communities even have to pay a higher price for many of their basic goods and services - a phenomenon called poverty penalty. High-income consumers spend a much smaller percentage of their resources on the basic necessities of life, leaving them enough money to purchase life enhancing items. While in most lowincome markets at least $50 \%$ of the income is spent just on food.

Individuals' limited access to or use of formal banking services pervades many emerging markets. In China and India, for instance, just one-third of the population has access to the formal banking sector. Recently however, some microfinance institutions have made initiatives in overcoming such a financial exclusion. Some non-financial industries are also employing specific business models to adapt to the conditions of lowincome markets (see box 1).

Casas Bahia, a retail chain in Brazil, tried to target low-income market in Brazil by overcoming the credit problem in such markets. 70 percent of its customers don't have a formal or consistent income .By providing a passbook scheme Casas Bahia enabled those without formal financial credit to make small installment payments for the goods. The salespeople also educated consumers to buy according to their budget. They benefited from addressing a large customer base while the low-income communities got the chance to buy appliances that they could not afford buying without having credit. Source: (Prahalad, 2005)

Box 1. Overcoming the low purchasing power barrier 
Low-purchasing power is a well known issue in developing studies. Since the purchasing power is far less than the top of the pyramid market, price reduction strategies that are common in high income markets and serve as a promotion strategy might not fit low-income markets.

Some companies have actively used innovative business models to overcome the price issue. A Model based on shared access is one of the most well-known models. Instead of charging the individual user for a good or service, these models provide the option of sharing the cost among the user community. For instance, instead of charging individual household for water services, Manila Water Company provides local communities the option of having collective installation for 3-4 households or a bulk of 40-50. This allows low-income communities to use water service while sharing costs among themselves to make it affordable for all.

Furthermore, low purchasing power customers may expect different functions from a product than the traditional high purchasing power customers. It is therefore important to identify the required functionalities instead of focusing on the product. For example, Unilever in India realized that in rural areas soaps are also used for washing hair, so they tried to make a body soap that contained healthy ingredients for the hair as well. Their 2 in 1 soap subsequently gained a large market share in rural areas. In another case, a Chinese appliance manufacturer, assigned a dedicated $R \& D$ team to understand the expectations of the rural user and accommodate them in their product(see box 2). 
In the mid 1990s Haier Group, a leading home appliance manufacturer in China, found out that many rural consumers used their washing machines not only to launder clothes, but also to do other tasks such as washing vegetables. Haier dedicated an $R \& D$ team to incorporate this matter. They modified that product by installing wider pipes that would not clog with vegetable peels. They also added instructions on the modified washers, with easy to understand directions on how to clean potatoes and other vegetables using the machine. They continued getting feedback from observing their rural customers and developed a modified washing machine to make cheese from milk. Strategies like these increased the acceptability of washing machines and helped Haier to gain a high market share in the competitive market of home appliances

Source : (Paine, 1998).

Box 2. Understanding and accommodating expected functions

\subsection{Dispersed locations}

Compared to the tip of the pyramid, the base of the pyramid represents a more diverse cultural variety and geography. In the majority of low-income markets, the availability of logistics infrastructure can not be taken for granted. That makes delivery, distribution and service of the product more difficult. In addition, limited access to media makes common ways of media advertisement less effective.

In order to access and educate consumers at low-income markets, a variety of approaches are needed: from simple method of billboards on walls and truck-mounted demonstrations to the use of local communities for spreading the word as way of mouth to mouth advertising (see box 3). 
Realizing the limitations of traditional marketing methods in low-income markets, Smart, a mobile company in Philippines, promoted kind of a viral marketing by using local entrepreneurs. It proved as an effective marketing way that popularized Smart's service and raised awareness about the service in a social way through friends, family and members of the entrepreneurs' local community. In addition, the entrepreneurs adopted the advertising method to the local conditions by putting advertising stickers on the local transportation means such as carts

Source: (Anderson and Billou, 2007).

Box 3. Marketing in remote locations

Currently there are more than 3 billion mobile phone users and obviously not all of them are rich. It is interesting to see how mobile usage has diffused among the rural communities and to see how new technologies can help people who could not utilize an older technology (i.e fixed line telephones) leapfrog and use a more sophisticated device which offers more value. In addition the use of mobile phone to offer services to becoming common in some low-income countries and businesses based on mobile are becoming wide spread.

\subsection{Lower skill/ knowledge}

It is generally known that higher user-friendliness of a product leads to higher acceptance rates of that product. There have been many cases where a new product that has been widely acclaimed by its producers has failed to diffuse in the market because consumers find the product very complicated to use. Sometimes engineers in R\&D departments get too much involved in the technical aspects that they tend to undermine the usability aspects. It is important to take into account the context in which the product is going to be used. Although this is not unique to a certain type of market, it 
seems to have vital implications in the base of the pyramid.

A considerable share of low-income population is illiterate, almost one fifth of adults around the world are functionally illiterate. In addition, they have less experience working with technology-intensive products or devices that require some level of prior skill or knowledge to operate. Hence it is important to redesign the user interface and product functions to make it acceptable and easy to use for those who lack the skill or knowledge to use the product. To serve such customers, some companies are working on simplified interfaces where minimum prior knowledge is required to use and operate the device. Using speech controlled devices that sends and receives voice commands is another approach suitable for certain types of products and services.

Educating the end-user is another way to overcome the problem. In lack of traditional channels for educating users, some companies have teamed up with Non government organizations(NGO) and local groups to do this task. For instance, CEMEX, a leading global building solutions company based in Mexico, offered not only affordable housing solutions through tailored business models, but also established a local network of trusted distributors to provide quality material and education on how to build house. Others, like Nokia have created a consumer education program in low-income markets (see box 4). 
In India, where lack of awareness and skill was considered as a major barrier for marketing products, Nokia started a consumer education program called "Connect". The idea of this program was to educate consumers about the different facets of mobile technology. Nokia planned to make it simple for consumers to use the different features and applications available on its phones.

As part of the Connect program, Nokia educated users about functionalities such as SMS and Bluetooth. Despite many features in handsets, there is still a general lack of awareness among users. By providing them a user-friendly guide, Nokia's "Connect" initiative helped consumers across the country to improve their mobile experience.

Source: Nokia India Press Release ,27/1/06 http://www.india-cellular.com/Press-Releases/Nokia27-1-06.html

Box 4. Educating users and overcoming lack of awareness

\subsection{Other challenges of low-income markets}

In addition to the above mentioned issues, low-income markets have other characteristics that challenge the business practices developed in advanced markets. In addition to such corporate challenges, many countries in low-income markets face political instability, volatile exchange rates, and an underdeveloped physical infrastructure that makes business even more difficult.

Much of the physical infrastructure conditions that are taken for granted in advanced markets are not available or is rather weak in low-income markets. Fluctuating electricity, and hostile environment (e.g. heat, moisture etc) require specific changes in product design, especially considering the fact that access to repair facilities is more difficult in such markets. The low degree of penetration of information and communication services together with limited transportation and logistics puts some 
major restrictions on the use of usual distribution models.. In addition, institutional factors pose another challenge; instable political system, different institutional structure, weak legal enforcement and intellectual property issues pose new rules of the game which many multinational companies are not familiar with.

The wide and scattered nature of low-income markets also requires extensive distribution networks that are viable at low volumes and low prices. The creation of such networks in low-income markets requires new partnerships and alliances that are not common in advanced markets. Partnerships of companies with financial institutions, non-governmental organization and other international institutions and their involvement in multi-stakeholder development projects are already taking place but still there is not much knowledge about the appropriate ways to create those networks effectively.

\section{The impact of low-income market characteristics on multinationals' strategy}

When entering new markets, companies have to leverage their resources and develop certain capabilities to be able to operate in the new environment. As we explained in the previous section, low-income markets have specific features which most of the multinational companies are unfamiliar with. Table 1 summarizes the main characteristics of low-income markets and the way in which core activities of multinationals in terms of $\mathrm{R} \& \mathrm{D}$, production and distribution/promotion have to be adapted to meet the challenges of those specific markets.

As to overcome the problem of low-purchasing power, some companies have put more 
attention on the improvement of the price-performance ratio and have started to focus on functionality in terms of offering a product that simply does the job without extra bells and whistles. In terms of production, considering the abundance of labor in lowincome markets, creating conditions for employing local labor in production can rise their income (i.e consumption power) while reducing the unit costs. For products like consumer goods, the low disposable income has been tackled by offering smaller packages of the good, while in terms of promoting the product, some companies have embedded financial services in their product offering to overcome the credit problem of these markets.

\begin{tabular}{|c|c|c|c|}
\hline \multicolumn{4}{|c|}{ Effect of low-income markets' characteristic on Multinationals' activities } \\
\hline & R\&D & Production & Distribution/Promotion \\
\hline $\begin{array}{l}\text { Low purchasing } \\
\text { power }\end{array}$ & $\begin{array}{l}\text { Focusing on } \\
\text { functionality, } \\
\text { improving } \\
\text { price/performance }\end{array}$ & $\begin{array}{l}\text { Smaller } \\
\text { packages/sachets, } \\
\text { using local } \\
\text { producers and local } \\
\text { labor }\end{array}$ & $\begin{array}{l}\text { combining financial } \\
\text { services with the product } \\
\text { collective payment option }\end{array}$ \\
\hline Dispersed locations & $\begin{array}{l}\text { developing scaleable } \\
\text { solutions, using local } \\
\text { entrepreneurs }\end{array}$ & $\begin{array}{l}\text { Partnering with } \\
\text { local producers } \\
\text {,modular design }\end{array}$ & $\begin{array}{l}\text { Partnering with civil } \\
\text { communities and NGOs }\end{array}$ \\
\hline $\begin{array}{l}\text { Lower } \\
\text { skill/knowledge }\end{array}$ & $\begin{array}{l}\text { Acknowledging } \\
\text { endogenous solutions, } \\
\text { proper user interface }\end{array}$ & $\begin{array}{l}\text { Robust production } \\
\text { to work in hostile } \\
\text { environments }\end{array}$ & $\begin{array}{l}\text { Customer education } \\
\text { programs , viral } \\
\text { marketing }\end{array}$ \\
\hline $\begin{array}{l}\text { weak } \\
\text { infrastructure, etc }\end{array}$ & \begin{tabular}{|l} 
Building local \\
research labratories, \\
turning infrastructure \\
constraints to sources \\
for innovation
\end{tabular} & $\begin{array}{l}\text { Build local } \\
\text { production capacity }\end{array}$ & $\begin{array}{l}\text { Creating dedicated } \\
\text { distribution network, } \\
\text { adapting to existing } \\
\text { means of transport }\end{array}$ \\
\hline
\end{tabular}

Table 2. Effect of low-income market characteristics on multinationals' activities 
To facilitate R\&D for dispersed locations, some companies have identified local entrepreneurs that act as local researcher with a better sense of local conditions. Setting up production units or partnering with local producers has been another solution to scale up operations. And since the main challenge in terms of distribution is the fact that often distribution channels are not available, a solution has been found in identifying and using local options and in some cases by setting up a dedicated distribution network. Furthermore a number of companies have started to work with local communities or non governmental organization (NGO).

In order to make the product acceptable and usable for the large number of less skilled customers in low-income markets, research has taken place by some companies to identify the solutions that communities already have developed on their own based on their culture, believes and endogenous knowledge. Instead of pushing a new proprietary product into the market, such locally-based approaches help to design a product with which consumers are familiar. It makes it easier for consumers to adapt when they make the shift to use the product. Since lack of education is another issue in such markets, some firms have tried to use specific user interfaces for their products and services that acknowledges this fact. Instead of using usual advertisement and marketing methods, some companies set up teams that go into the communities and offer education and awareness about the benefits and use of the products. However, the effectiveness and appropriate ways for such awareness programs needs to be studied further.

In most cases, companies are engaged in activities that they have not done before, 
something that is quite different from their conventional business models in mainstream markets. By using creative solutions they have tried to respond to the limitations of lowincome markets and turn the challenges to opportunities. It is interesting to see how companies try to understand the requirements and needs of this different context. In most of the solutions, multinationals have engaged in new partnerships, for example with local producers, suppliers and also NGOs.

\section{Conclusion and implications}

There is an ongoing debate in the academic literature and practice about the specific role of companies in low-income markets. An increasing body of so-called BOP literature argues that once companies figure out how to serve low-income consumers in developing countries profitably, everyone might benefit: the underserved communities gain access to products and services that the private sector is best positioned to deliver, while companies benefit from tapping into vast new markets. On top of that, when core sectors of the economy- such as banking, electricity, telecommunications - progress, they might transform consumers into producers, thereby enhancing economic development (Beshouri 2006).

But there seems to be a long road ahead to eventually reach this goal. Multinational corporations have a long history of dramatic failures in low-income markets. Practicing business "as usual" in low-income markets has proven to be a recipe for failure. In this chapter we therefore argue that corporate strategies need to be redefined when it comes to addressing low-income markets. Various limitations and constraints of low-income markets require firms to think of creative new ways in order to benefit from the so-far 
untapped high-growth markets. A new approach is needed in which social embeddings and understanding the local context are key to offering what might be called “appropriate innovation”.

Creating new partnerships and networks for serving low-income markets is another piece of puzzle. Many companies are pursuing ways to increase social impact in their profit-making business mandates (Brugmann and Prahalad, 2007). Some nongovernmental organizations (NGO), on the other hand, are joining forces with the private sector to foster socioeconomic development. The intention is to share competencies, networks, infrastructure and know-how required to operate in lowincome markets. Such partnerships are new for both sides and hence both sides face difficulties in adapting to it. Capacity for partnerships with many different stakeholders (government, NGOs, social organizations, banks, etc), with diverse ways-of-working and interests is a challenging task that has yet to be addressed.

Overall we can argue that low-income markets provide companies with many new business opportunities. However, the specific characteristics of these markets increasingly challenge the existing practices of multinational corporations. Successful companies have therefore embraced a completely new way of organizing for lowincome markets based on embracing local practices, local innovation, local distribution systems and local production/sales systems. In order to access these local resources, collaboration with both the local community as well as with NGOs seems to be crucial for corporate success and BOP development. 


\section{References}

Anderson, J. and Billou, N. (2007). 'Serving the World's Poor: Innovation at the Base of the Economic Pyramid', Journal of Business Strategy 28(2), 14-21

Caves, R.E. (2007). Multinational enterprise and economic analysis. Cambridge ; New York, Cambridge University Press

Christensen, C., Baumann, H., Ruggles R., and Sadtler, T. (2006), 'Disruptive Innovation for Social Change', Harvard Business Review, 84(12), 94-101.

Beshouri, C. P. (2006), 'A grassroots approach to emerging-market consumers', McKinsey Quarterly (4), 60-71.

Brugmann, J. and. Prahalad, C. K ( 2007), 'Cocreating Business's New Social Compact.' Harvard Business Review, 85(2), 80-90.

Dawar, N. and A. Chattopadhyay (2002), 'Rethinking Marketing Programs for Emerging Markets', Long Range Planning 35(5), 457-474.

Grayson, D. and A. Hodges (2004). Corporate social opportunity! : 7 steps to make corporate social responsibility work for your business. Sheffield, Greenleaf.

Hart, S.L. (2005). Capitalism at the crossroads: The unlimited business opportunities in solving the world's most difficult problems. Upper Saddle River, NJ: Wharton School Publishing.

Hart, S.L. and Christensen, C.M. (2002), 'The great leap: driving innovation from the base of the pyramid', Sloan Management Review 44(1), 51-56

Hart, S.L. and Milstein M.B. (1999), 'Global Sustainability and the Creative Destruction of Industries', Sloan Management Review, 41(1), 23-33.

Hammond A., Kramer, W., Katz ,R., Tran, J., and Walker, C. (2007), The Next 4 Billion: Market Size and Business Strategy at the Base of the Pyramid, World 
Resources Institute

Hammond, A. and Prahalad, C.K (2004), 'Selling to the poor', Foreign Policy(142): 30.

Karnani, A. (2007), 'The Mirage of Marketing to the Bottom of the Pyramid: How the private sector can help alleviate poverty', California Management Review, 49(4), 90-111.

London, T. and Hart S.L (2004), 'Reinventing strategies for emerging markets: beyond the transnational model', Journal of International Business Studies, 35(5), 35070.

Paine,S. and Crawford, R.J. (1998), 'The Haier Group A', Harvard Business School case study no. 398101, Harvard Business School Publishing.

Porritt, J. (2005), Capitalism as if the world matters. London ; Sterling, VA: Earthscan.

Prahalad, C. K. (2005), The fortune at the bottom of the pyramid eradicating poverty through profits . Upper Saddle River, NJ, Wharton School Publications

Prahalad, C.K and Hart, S. (2002), 'The fortune at the bottom of the pyramid' , Strategy+Business, 26:54-67

Prahalad, C. K. and Kenneth Lieberthal. (1998), 'The end of Corporate Imperialism', Harvard Business Review, 76(4), 68-79.

Ramamurti, R. (2004) 'Developing countries and MNEs: extending and enriching the research agenda', Journal of International Business Studies, 35(4):277

Rangan, V. K. (2007), Business solutions for the global poor : creating social and economic value. San Francisco: Jossey-Bass. 
Sabharwal Ahmad, P., Egorman M., Werhane, P., (2004), 'Case Study: Hindustan Lever Limited and marketing to the poorest of the poor', International Journal of Entrepreneurship and Innovation Management, 4(5): 495 - 511.

De Soto, H. (2000), The mystery of capital : why captitalism triumphs in the West and fails everywhere else. New York: Basic Books.

UNDP (2007), Growing Inclusive Markets, New York, United Nations Development Programme.

Von Hippel, E. (2005). Democratizing innovation, Cambridge, Mass., MIT Press.

World Resources Institute (WRI) and the International Finance Corporation (IFC), 2007. Next Four Billion: Market Size \& Business Strategy at the Base of the Pyramid, Washington, D.C.: WRI.

\footnotetext{
${ }^{\mathrm{i}}$ PPP exchange rates estimate the value of a currency in terms of the basket of goods that it buys (compared with the cost of a similar basket in a reference country and currency) rather than in terms of the existing market exchange rates, hence providing a standardized comparison of real prices.
} 


\section{The UNU-MERIT WORKING Paper Series}

2008-01 Science, Technology and Development: Emerging concepts and visions by Luc Soete

2008-02 Reframing technical change: Livestock Fodder Scarcity Revisited as Innovation Capacity Scarcity. Part 1. A Review of Historical and Recent Experiences by Andy Hall, Rasheed Sulaiman V., Mona Dhamankar, Peter Bezkorowajnyj \& Leela Prasad

2008-03 Reframing technical change: Livestock Fodder Scarcity Revisited as Innovation Capacity Scarcity. Part 2. A Framework for Analysis by Andy Hall, Rasheed Sulaiman, V. and Peter Bezkorowajnyj

2008-04 Reframing technical change: Livestock Fodder Scarcity Revisited as Innovation Capacity Scarcity.Part 3. Tools for Diagnosis and Institutional Change in Innovation Systems by Andy Hall, Rasheed Sulaiman and Peter Bezkorowajnyj

2008-05 Is Inter-Firm Labor Mobility a Channel of Knowledge Spillovers? Evidence from a Linked Employer-Employee Panel by Mika Maliranta, Pierre Mohnen \& Petri Rouvinen

2008-06 Financial Constraints and Other Obstacles:Are they a Threat to Innovation Activity? By P. Mohnen, F.C. Palm, S. Schim van der Loeff and A. Tiwari

2008-07 Knowledge-based productivity in 'low-tech' industries: evidence from firms in developing countries by Micheline Goedhuys, Norbert Janz and Pierre Mohnen

2008-08 The Voyage of the Beagle in Innovation Systems Land.Explorations on Sectors, Innovation, Heterogeneity and Selection by Martin Srholec \& Bart Verspagen

2008-09 Crafting Firm Competencies to Improve Innovative Performance by Boris Lokshin, Anita van Gils \& Eva Bauer

2008-10 The Economics and Psychology of Personality Traits by Lex Borghans, Angela Lee Duckworth, James J. Heckman \& Bas ter Weel

2008-11 Embedding Research in Society: Development Assistance Options for Supporting Agricultural Innovation in a Global Knowledge Economy by Andy Hall

2008-12 Playing in Invisible Markets: Innovations in the Market for Toilets to Harness the Economic Power of the Poor by Shyama V. Ramani

2008-13 Explaining Success and Failure in Development by Adam Szirmai

2008-14 Running The Marathon by William Cowan, Robin Cowan and Patrick Llerena

2008-15 Productivity effects of innovation, stress and social relations by Rifka Weehuizen, Bulat Sanditov and Robin Cowan

2008-16 Entrepreneurship and Innovation Strategies in ICT SMEs in Enlarged Europe (EU25) by Kaushalesh Lal and Theo Dunnewijk 
2008-17 Knowledge Transfers between Canadian Business Enterprises and Universities: Does Distance Matter? By Julio M. Rosa \& Pierre Mohnen

2008-18 Multinationals are Multicultural Units: Some Indications from a Cross-Cultural Study by Nantawan Noi Kwanjai \& J. Friso den Hertog

2008-19 The Innovativeness of Foreign Firms in China by Branka Urem, Ludovico Alcorta and Tongliang An

2008-20 Beyond the emission market: Kyoto and the international expansion of waste management firms by Ionara Costa, Asel Doranova and Geert-Jan Eenhoorn

2008-21 The 'making of' national giants: technology and governments shaping the international expansion of oil companies from Brazil and China by Flavia Carvalho and Andrea Goldstein

2008-22 If the Alliance Fits . . . : Innovation and Network Dynamics by Robin Cowan \& Nicolas Jonard

2008-23 Facing the Trial of Internationalizing Clinical Trials to Developing Countries: With Some Evidence from Mexico by Fernando Santiago-Rodriguez

2008-24 Serving low-income markets: Rethinking Multinational Corporations' Strategies by Shuan SadreGhazi and Geert Duysters 